\title{
SPINOZA ON ESSENCES, UNIVERSALS, AND BEINGS OF REASON
}

BY

\author{
KAROLINA HÜBNER
}

\begin{abstract}
The article proposes a new solution to the long-standing problem of the universality of essences in Spinoza's ontology. It argues that, according to Spinoza, particular things in nature possess unique essences, but that these essences coexist with more general, mind-dependent species-essences, constructed by finite minds on the basis of similarities ('agreements') that obtain among the properties of formally-real particulars. This account provides the best fit both with the textual evidence and with Spinoza's other metaphysical and epistemological commitments. The article offers new readings of how Spinoza understands not just the nature of essence, but also the nature of being, reason, striving, definitions, and different kinds of knowledge.
\end{abstract}

\section{Introduction}

Where does Spinoza stand on the question of the universality of natures or - to put it in what are arguably equivalent terms within his framework - 'essences [essentiae]'? ${ }^{1}$ That is, does he hold that in metaphysical rigour the essence that characterizes each thing uniquely characterizes this res and nothing else? Or does he hold that essences can also, or perhaps exclusively, belong to kinds, such that several distinct ${ }^{2}$ entities can share one and the same nature?

The question is a basic one, yet to this day there is no consensus as to Spinoza's answer to it. Readers have attributed to Spinoza positions ranging from Platonic realism to varieties of nominalism. ${ }^{3}$ And prima facie at least there does seem to be textual evidence both for what we could call a 'universalist' reading - on which Spinoza would allow for something like

Pacific Philosophical Quarterly ••(2015) ••-• DOI: 10.1111/papq.12087

(C) 2015 The Author

Pacific Philosophical Quarterly (C) 2015 University of Southern California and John Wiley \& Sons Ltd. 
more general, or species-essences - and for a 'particularist' reading - on which Spinoza would hold that the essences of particular things are unique to them. ${ }^{4}$ This ostensible inconsistency of the textual evidence has led Della Rocca for one to conclude that Spinoza relies on two 'contradictory' notions of 'essence', generating a 'deep tension' within his own metaphysics. ${ }^{5}$ Perhaps it is because Spinoza's position on this matter has begun to seem hopelessly conflicted that the issue has largely disappeared from the scholarly radar, ${ }^{6}$ despite the obvious importance that the notion of 'essence' has for Spinoza's philosophy, not just within his metaphysics. In particular, as we shall see in more detail later (3.1), the kind 'human' appears to be a condition of the possibility of many of Spinoza's mature moral and political doctrines. So clarifying Spinoza's stance on the problem of the universality of essences would not only reconcile prima facie incongruous texts, and shed light on a basic building block of his metaphysics; it would also let us move us closer to an adequately systematic interpretation of Spinoza's later philosophy one that intelligibly grounds his moral doctrines in his metaphysical theses.

In what follows I propose a new account of Spinozistic essences, one that hopes to resolve the above problems. To anticipate, I argue that Spinoza is committed to a middle position between 'universalism' and 'particularism' as defined above. For reasons that will shortly become clear, I call this middle position 'constructivism'. Briefly, on a constructivist reading of Spinoza, particular things in nature (that is, entities endowed with formal reality ${ }^{7}$ and incapable of existing in, or as a constituent of, many distinct things at the same time) do indeed possess unique essences. But constructivism diverges from more restrictive versions of particularism (on which such unique essences would be the only essences allowed within Spinoza's framework), in asserting that these unique essences of really existing particulars coexist with more general (less determinate) mind-dependent species-essences. The latter essences possess objective reality alone, qua 'beings of reason [entia rationis]' represented by finite minds and constructed by them on the basis of similarities ('agreements') among the properties of formally-real particulars. Moreover, such constructions can result in adequate universal or general notions if they are due to the activity of 'reason [ratio]', and based on properties that render the essences of particulars genuinely similar.

A concrete example may be useful here: on the constructivist reading, Spinoza claims both that my pet spider Vladimir, currently crawling up the window, has a unique essence (without which he cannot exist, and which likewise cannot exist without him [E2def2]), and that there is (in a purely ideal sense of 'being') a universal arachnid nature, by means of which I can represent, either adequately or not, both Vladimir and his window-mate Estragon.

On the constructivist reading then, the term 'essence' indeed turns out to have two senses for Spinoza, as Della Rocca charges. But this, I suggest, is a consequence of a principled metaphysical and epistemological position, 
not of equivocation or inconsistency. The constructivist account shows that exclusively particularist and universalist interpretations of Spinozistic essences are on their own incomplete. But it also illuminates what makes each of them appear so plausible.

I spend the rest of the article filling in the details of the above account, and showing how it dovetails both with the textual evidence and with Spinoza's other metaphysical and epistemological commitments. But even those unpersuaded by this constructivist reading must, I think, concede at least the following, more general, point. This is that even if Spinoza speaks about 'essences' sometimes as if belonged to kinds and sometimes as if they belonged to particulars, on its own this does not yet merit a charge of inconsistency. Such a charge would overlook the possibility that for Spinoza essences may characterize both kinds and particulars, such that there are essences at various levels of generality: an essence to 'being' as such, to being a spider specifically, to being Estragon in particular, etc. What can lead us to think that Spinoza is caught in a contradiction here is the assumption that universalist and particularist conceptions of essence are incompatible. But I am not aware of any textual evidence that Spinoza shares this assumption. Nor does there seem to be any inherent conceptual impossibility, or historical implausibility, in the coexistence of such more- and less-determinate essences. ${ }^{8}$ And once we recognize this, accusations of inconsistency simply do not get off the ground.

Let me say a few words finally about how the article will unfold. Sections 2 and 3 serve as preliminary surveys of textual evidence; they will also help us identify the interpretative problems that any account of Spinozistic essences must address, and bearing on Spinoza's conception of definition, 'striving', and different kinds of knowledge. Section 2 assesses the textual evidence for a particularist reading of Spinoza; Section 3, for a universalist one. Section 4 is the core of the article, laying out the constructivist account of his metaphysics.

\section{Spinoza as a particularist}

2.1.

Let me start with Spinoza's official definition of 'essence', or his statement of the nature of essence?

... to the essence of any thing belongs that which, being given, the thing is $\left[\mathrm{NS}^{10}\right.$ : also] necessarily posited and which, being taken away, the thing is necessarily [NS: also] taken away; or [vel] that without which the thing can neither be nor be conceived, and which can neither be nor be conceived without the thing (E2def2).

One plausible way to gloss this definition is to say that for Spinoza, the essence of a thing is the property (or set of properties) necessary and sufficient 
for the existence (being, givenness) of this thing. ${ }^{11}$ There cannot be an 'essence' without there being a res endowed with that essence, and vice versa. The definition is, I suggest, neutral on the kinds of 'being', 'positing' or 'givenness' at stake. That is, it applies equally to all the different kinds of 'being' that Spinoza admits in his metaphysics: to 'being' in the sense of 'actually' existing in space and time; to 'being' qua 'formal essence' implicit in substantial essence; and finally to being merely thought of - that is, to 'being' qua objective reality of some idea. ${ }^{12}$ E2def2 states that if a thing's essence is in any of these senses, the corresponding res also is, in the same sense - and vice versa.

With this initial characterization of Spinozistic essences on the table, let me turn to evidence for particularist construals of this essence - that is, for the claim that Spinoza holds that formally-real particulars possess unique essences. To anticipate, I shall conclude that (1) Spinoza is indeed committed to the existence of unique essences of particulars in nature; but that (2) this is not for reasons usually cited; and (3) this does not rule out the existence of more general species-essences alongside the unique essences of particulars.

\section{2.}

I will begin with an argument that is typically overlooked in the debates about the universality of Spinozistic essences. ${ }^{13}$ Yet it offers very straightforward evidence that Spinoza does indeed allow that at least some particulars possess unique essences.

The argument in question follows from Spinoza's well-known commitment to substance-monism, and more specifically from his belief that it is metaphysically impossible for the essence of substance (an essentially independent entity) to have more than one instance (E1p5). This establishes the necessary uniqueness of at least one essence in nature, namely the essence of substance. ${ }^{14}$ In so doing, it rules out a first possible interpretation of Spinozistic essences, namely any quasi-Platonic reading allowing solely for more general species-essences.

However, we have not yet ruled out the possibility that the essences of modes (essentially dependent entities) will prove to be unlike substantial essence in not being unique to the things that have them. That is, we have not yet vindicated particularism as a perfectly general metaphysical doctrine, on which all Spinozistic essences uniquely characterize particulars.

Let me turn then to arguments that seem to promise to establish this more general particularism. To anticipate, I shall argue that there is no successful argument for this conclusion.

\section{3 .}

Let's consider, first, Spinoza's conatus doctrine, which specifies what any existing thing, considered solely in its essential nature, must and can do. 
Its key claim is that 'Each thing, as far as it is in itself, strives to persevere in its being [suo esse]' (E3p6). Some commentators have taken this reference to 'suo esse' to reveal a general commitment to particularism on Spinoza's part. ${ }^{15}$ The thought is that his use of this phrase shows that the 'being' every thing strives to preserve is its unique being as a determinate particular. On this reading then, the uniqueness of each thing's essence - i.e. a general particularism about essence - is demanded by the conatus doctrine, insofar as this universal ${ }^{16}$ causal law turns out to be concerned with the preservation of something unique. In other words, on this reading, Spinoza's particularism about essences must be as general in scope as the conatus doctrine.

Unfortunately for the advocate of particularist readings of Spinoza, the argument is flawed. This is because particularism follows from E3p6 only if we assume, in a question-begging way, that the phrase 'its being' refers to properties unique to the striving particular. But nothing forces this reading of 'suo esse'. Recall for instance Descartes's remark that 'in Peter himself being a man is nothing other than being Peter' (Letter to unknown, 1645 or 1646; AT4.348). For Descartes, in re Peter's 'humanity' is not distinct from Peter's own being qua particular, and can presumably be also described as Peter's 'own' being. ${ }^{17}$ It is not clear that we can rule out that Spinoza holds a very similar view of the relation of particulars to universal natures. In such a case his description of persevering as persevering 'in suo esse' cannot decide the universality or particularity of Spinozistic essences: E3p6 will be compatible both with the view that particulars strive in some distinctive being (that is, produce the effects that are the necessary consequences of their unique essences), and with the view that they strive in the being they share with others of the same kind (and so produce certain effects qua spiders for example). ${ }^{18}$

2.4 .

As we just saw, E3p6 cannot be used to establish a generalized particularist reading of Spinozistic essences. Let's try then another argument. This one draws on Spinoza's notion of scientia intuitiva. Spinoza describes this kind of cognition as 'proceed[ing] from an adequate idea of the formal essence of certain attributes ${ }^{19}$ of God to the adequate cognition of the [NS: formal] essence of things' (E2p40s2[IV]; II/122; trans. alt.). The argument hinges on the common assumption that the creaturely essences that are known in scientia intuitiva are the unique essences of particulars. ${ }^{20}$ Hence, if we also assume that according to Spinoza it is in principle at least possible to have intuitive knowledge of all things, all things must have unique essences.

Unfortunately, it's not clear that textually this argument for particularism has a leg to stand on. ${ }^{21}$ The two relatively detailed examples of intuition Spinoza offers in the Ethics fail to shore up the assumption that it is the unique essences of particulars that form the proper object of intuition. In 
the first example, Spinoza describes himself as having shown how 'our Mind [mens nostra]...follows from the divine nature' in order:

... to show by this example how much the knowledge of singular things [rerum singularium] I have called intuitive ... can accomplish, and how much more powerful it is than the universal knowledge [cognitione universali] ... For although I have shown generally [generaliter] in Part I that all things (and consequently the human Mind also [omnia et consequenter mentem etiam humanam]) depend on God ... nevertheless, that demonstration ... still does not affect our Mind as much as when this is inferred from the very essence of any singular thing which we say depends on God (E5p36s; II/303; my ital.).

Some of Spinoza's language here indeed is redolent of particularism, as when he describes intuition as cognition of 'singular' things (that is, by E2def7, of finite and determinately existing things). But overall the passage does not bear out this reading. For the essence that forms the object of intuition in this example - the essence seen to follow from the essence of substance - is what I've called a more general species-essence: namely, the essence of the 'human mind'. This suggests that at least in some cases of intuition, to know the essence of a singular thing 'intuitively' is not to know something unique to a particular thing (for example, the essence of my mind in contrast to the essence of Spinoza's mind), but rather the common essence of a certain kind of singular thing (our shared human essence under the attribute of thought).

It is true that the passage contrasts 'intuitive' cognition with 'universal' cognition, which at first blush might seem to bolster particularist accounts. In fact, however, the contrast is not intended to hold insofar as only 'universal' cognition but not 'intuitive' cognition would constitute a cognition of species-essences. ${ }^{22}$ By 'universal' cognition in this passage Spinoza understands cognition of what pertains to all things. This sort of cognition can then become the ground for further conclusions about specific kinds of things (for example, human minds). ${ }^{23}$ That is, the relevant contrast is between knowing ('universally') a truth about all things, and knowing ('intuitively'), without mediation by some more general truth, a truth about a certain kind of finite thing. In short, this first example of intuitive cognition does not vindicate generalized particularism about Spinozistic essences, since in at least some cases Spinozistic intuition turns out to constitute a cognition of species-essences.

The Ethics' second example of scientia intuitiva fares no better in this respect. ${ }^{24}$ The example in question is Spinoza's well-known mathematical illustration of 'seeing' the missing fourth proportional - solving for $n$ in $1 / 2=3 / n(\mathrm{E} 2 \mathrm{p} 40 \mathrm{~s} 2 ; \mathrm{II} / 122) .{ }^{25}$ There are two different ways to understand this example. On the first reading, intuition delivers cognition of the essence of the proportion of the relevant numbers. But a proportion is a relation; it does not constitute the essence of any particular thing. ${ }^{26}$ So, on this reading, the example also fails to show that Spinozistic intuition 
requires the existence of the unique essences of particulars; hence it cannot be used to bolster particularist readings. On the second interpretation of the example, the essence that is the object of intuition is the essence of the missing fourth number - the essence of the number 6 . Here a few words of background will be useful: Spinoza regards numbers as mind-dependent beings of reason that allow us to determine real beings in thought in abstraction from their ontological grounding in substance (Ep.12; I/56). ${ }^{27}$ More precisely, numbers 'serve to explain a thing by determining it through comparison to another' in terms of the abstract property of 'discrete quantity' (CM1.1; I/234). ${ }^{28}$ In this way we can represent a collection of particulars simply as numbering ' 6 ' for example, instead of representing them as unique substantial affections. But abstract representations such as ' 6 ' can be predicated of potentially infinitely many different sets of affections; hence, by Spinoza's own lights, 6 represents a universal. (Universals, writes Spinoza, are what is 'predicate[d] of infinitely many singulars' and expresses 'what they all agree in' or 'what is common to all' of them [E2p40s1; II/121]. ${ }^{29}$ So if we understand the object of intuition in Spinoza's second, mathematical, example of scientia intuitiva to be the essence of a number, we will have to grant once again that at least sometimes intuition is a cognition of the essences of universals.

We can conclude then that Spinoza's second example of scientia intuitiva, whichever of the two ways it is interpreted, fails to show that Spinoza's notion of intuition requires a particularist reading of essence.

\section{5}

The argument I want to consider next is the single most cited piece of evidence for the claim that all Spinozistic essences are unique to particulars. This is the Ethics' official definition of essence, E2def2, which I cited in 2.1. The definition is widely regarded as proof that Spinozistic essences are without exception unique. ${ }^{30}$ This is because (so goes the claim) a species-essence could be 'given' without any number of corresponding 'things' (i.e. particulars endowed with that nature) likewise being 'given', contravening E2def2. ${ }^{31}$

This is certainly a natural gloss of the definition. Nonetheless, I suggest that it is a mistake to see E2def2 as on it own proof that Spinozistic essences are without exception unique to particulars. For to read the definition in this way is to assume (once again, in a question-begging way) that E2def2's reference to 'things' is a reference to particular things alone. But there seems to be no good reason why the 'things' the definition mentions could not figure also at higher levels of generality - that is, why the 'things' in question could not be less determine entities such as 'human being' or 'animal'. It seems perfectly coherent to say that it follows from E2def2 that for Spinoza 'to the essence of an animal belongs that which, being given, an animal is also necessarily posited'. I suggest then that E2def2 simply leaves 
undetermined the level of generality proper to the 'essences' and 'things' it invokes. Hence, also the definition cannot show that particularist construals of Spinozistic essences, as opposed to the universalist ones, are correct. All it allows us to establish is the following weaker, conditional claim: if there are particular things, these will be endowed with distinct (unique) essences; but, also: if there are less determinate things, these will be endowed with appropriately less determinate essences. In short, E2def2 lets us make some advance on the issue at hand in this article, but it is not the advance that the proponent of particularism had in mind.

\section{6.}

There is one more argument one could make for unrestrictedly particularist readings of Spinoza's ontology, i.e. for readings that rule out the possibility of more general species-essences. This argument draws on Spinoza's wellknown criticisms of universals. The thought is that if Spinoza does not accept the legitimacy of 'universals', 'genera', 'species', 'general notions' and 'abstractions', then a fortiori he cannot accept the legitimacy of species-essences.

Spinoza indeed distances himself from universals, abstractions and general notions throughout his writings. In Ep.12, for instance, he equates 'abstract' thinking with 'superficial' thinking, warning that it leads to 'absurdities' (I/56-7). In similar spirit, in the Treatise on the Emendation of the Intellect (TIE), he denounces universals and abstractions as notions that fail to represent anything real:

... so long as we are dealing with the Investigation of things, we must never infer anything from abstractions [abstractis], and ... mix up [misceamus] [things] that are only in the intellect [tantum sunt in intellectu] with those that are real [sunt in re] ... [T] he best conclusion will have to be drawn from some particular affirmative essence [essentia aliqua particulari affirmativa] ... [I]t is necessary ... always to deduce all our ideas from Physical things, or from the real beings [physicis sive...realibus] ... in such a way that we do not pass over [transeamus] to abstractions and universals [universalia], neither inferring something real from them, nor inferring them from something real (TIE[93, 99]). ${ }^{32}$

In Metaphysical Thoughts (CM) Spinoza reiterates that ideas representing 'genera' and 'species' are 'not ideas of things [ideas rerum]' and 'have no object [ideatum] that exists necessarily, or can exist ... [I] f anyone looks outside the intellect [extra intellectum] for what is signified by those words, he will find it to be a mere nothing [merum nihil]' (CM1.1, I/234-5). In fact, only 'singular things' are 'really existing things [res realiter existentes]', knowable by God (CM2.7; I/262-3). Genera and species are nothing more than mnemonic devices invented by philosophers wishing to 'reduce' 'all natural things to certain classes [classes]' (CM1.1; I/234). 
Spinoza draws a similar conclusion in the Short Treatise (KV): it is 'ignorance' to conclude 'that God has no knowledge of particular and corruptible things, but only of universals': 'all and only the particulars [bijzondere] have a cause, not the universals [algemeene], because they are nothing [niets]. God...is a cause of, and provider for, only particular things' (KV1.6; I/43). ${ }^{33}$ Universals are neither produced nor known by God; hence they lack formal reality. As such, they also lack causal power, as Spinoza explains using the example of 'will' and 'intellect':

... they seem to me to be universals, and I cannot attribute anything real to them ... Possibly this will not satisfy some, who are accustomed to occupy themselves more with Beings of Reason [Entia rationis] than with the particular things which are truly in Nature [Bijzondere dingen die waarlijk in de Natur zijn]. In doing this, they consider the Being of Reason not as what it is, but as a Real Being [ens reale] ... But since ... the Will is only an Idea of this or that volition (and therefore only a mode of thinking, a Being of Reason, not a Real Being), nothing can be produced by it. For nothing comes of nothing (KV2.16; I/81-2).

This line of thought continues into the Ethics. There Spinoza declares that the most general of general ideas, that of 'being [ens]', reflects merely how we are 'accustomed [solemus]' to think, what we 'say' and what we 'call' things (E4pref; II/207). Likewise, in a much-cited scholium that constitutes Spinoza's most extensive treatment of general notions anywhere in his corpus, he concludes that 'transcendental ... terms [termini transcendentales] like Being, Thing and something' and 'Universal [notions] [notiones... universales], like Man, Horse, Dog' 'signify ideas ... confused in the highest degree' (E2p40s1; II/120-1).

Given this steady stream of criticism directed at universals, abstractions, genera, species, universal notions and general terms, it is unsurprising that the lesson many readers have taken away from such passages is that Spinoza rejects all metaphysical and conceptual generality. The specific formulations of this conclusion vary. Margaret Wilson attributes to Spinoza a principled avoidance of all 'abstractions'; Curley of 'general ideas'; Pollock of 'abstractions' and 'universals'; Savan of language in general; finally Melamed speaks of a 'confusion involved in conceiving universals' and, like Matson, equates universals with mere 'aids to the imagination'. ${ }^{34}$ If such assessments of Spinoza's position were correct, we would indeed have reason to conclude that particularist readings of Spinozistic essences are also correct. For if Spinoza regards all universals, species, and general terms as philosophically unsound, then a fortiori he cannot admit species-essences in his own ontology.

In fact, however, the suggestion that Spinoza simply rejects all universals and general ideas does not withstand scrutiny. This is so for at least two reasons. First, there are Spinoza's other epistemological commitments. In particular, a well-known tenet of Spinozistic epistemology is that 'common notions', and what follows from them, are necessarily adequate (E2p38-40). 
However, common notions are obviously general in some sense - namely insofar as they represent either the ubiquitous consequences of substance's essential nature (the universally-instantiated properties that contribute to the constitution of every entity under a given attribute), or the pervasive properties that contribute to the constitution of entities within one's causal environment (E2p39). ${ }^{35}$ But if common notions were vulnerable to criticisms of general idea laid out in E2p40s1, Spinoza would be guilty of inconsistency (in neighbouring scholia to boot, since the nature of 'reason', which is grounded in common notions, is laid out in E2p40s2). And some commentators indeed accept that the two scholia are in tension. ${ }^{36}$ But I want to deny this. This is not because I think that common notions are mere 'aids to the imagination', as some propose, ${ }^{37}$ and so are just as inadequate as the notions criticized in E2p40s1. Rather there is no tension between the two scholia - and, more generally, between Spinoza's doctrine of common notions and his criticisms of general ideas - because Spinoza's criticisms in E2p40s1 do not in fact amount to a simple rejection of all general notions and universals, contrary to how this scholium is usually construed.

This is the second problem with the common thesis that Spinoza eschews all general notions and universals: this thesis - one that, if true, would establish the correctness of unrestrictedly particularist readings of Spinozistic essence - is not only inconsistent with Spinoza's epistemological commitment to the adequacy of at least some general notions (namely common notions); the textual grounds for this thesis are also lacking. For Spinoza's writings do not in fact support the claim that he simply rejects abstractions, universals, and species tout court. Consider again Ep.12, TIE[93, 99] and KV2.16, cited above. These passages confirm what we have put earlier (2.5) in purely conditional terms, namely they show that Spinoza is indeed committed to the existence in nature -i.e. to the formal reality - of a multiplicity of distinct particulars. ${ }^{38}$ These are the 'this and that's' endowed with genuine causal powers, 'slight differences' and 'affirmative' essences. ${ }^{39}$ Spinoza is also committed to the further claim that only such particulars have formal reality. Universals (and other beings of reason) are in his view merely ideal - that is, they have merely objective reality, as products of our mental acts. And in these texts Spinoza is urging us not to confuse the real and the ideal: not to 'pass over' from beings of reason to real beings, not to 'mix' up the two, endowing the ideal with properties of real things (properties such as being a genuine cause; or being caused and known by God) ${ }^{40}$ In short, the texts in question support not the thesis of a wholesale rejection of metaphysical and conceptual generality, but only the weaker injunction to distinguish what is formally real from what is ideal.

Likewise, Spinoza's criticisms in E2p40s1 are not a simple rejection of all general notions and terms (one that would be apt to be in tension with his doctrine of common notions). The criticisms have a very specific and relatively narrow target. Spinoza never explicitly names it, but his use of the Aristotelian term 'transcendental' is a conspicuous clue. Namely, 
Spinoza's true adversary in E2p40s1 is the Aristotelian principle that we can acquire a true knowledge of things' essences through sense-experience. ${ }^{41}$ E2p40s1 rejects this principle, and offers an alternative account of the relation between universals and sense-experience. That account starts from the premise that the finitude of our bodies allows them to form only a limited number of 'distinct' 'images' of the external bodies we interact with:

... when the images in the body are completely confused, the Mind also will imagine all the bodies confusedly, without any distinction, and comprehend them as if under one attribute ... [S]o many images (e.g., of men) are formed at one time ... that they surpass the power of imagining ... to the point where the Mind can imagine neither slight differences of the singulars [singulorum parvas differentias] (such as the color and size of each one, etc.) nor their determinate number, and imagines distinctly only what they all agree in, insofar as they affect the body ... And [NS: the mind] expresses this by the word [']man['], and predicates it of infinitely many singulars' (E2p40s1; II/120-1; my ital.). ${ }^{42}$

Such empirically-formed general notions and the terms that refer to them are the sole target of Spinoza's opprobrium in E2p40s1. In Spinoza's view senseexperience (i.e., the formation of ideas representing bodily affections) allows us to form only one kind of adequate idea: the aforementioned common notions. All other general notions formed in sense-experience are merely an idiosyncratic record of how one body happens to be affected by other bodies. Such notions can represent distinctly only the relative properties of certain arbitrary collections of bodies, collections that moreover vary from one perceiver to the next. So we are in error if we think, as an Aristotelian would, that sense-experience will lead us to form true representations of the essences of things.

In short, both the internal consistency of Spinoza's epistemology and textual considerations undermine the claim that Spinoza rejects all general notions and universals, and with them implicitly all species-essences. ${ }^{43}$

2.7 .

Let us take stock. After discussion in this section, we are in a position to draw the following conclusions:

First of all, after scrutinizing a number of possible arguments for particularist interpretations of Spinoza's metaphysics, we have yet to find one that successfully establishes his commitment to the uniqueness of all essences (i.e. to a generalized or unrestricted particularism). Secondly, the passages surveyed in 2.6 confirmed, as we saw, that Spinoza is committed to the existence in nature of a multiplicity of distinct particulars. As noted earlier (2.5), it follows from this and from Spinoza's definition of definition that he is also committed to the existence in nature of the unique essences of such formally-real particulars. (This is because E2def2 requires that any distinct, formally-real particular be endowed with a unique and formally-real essence, which forms a necessary 
and sufficient condition of this particular's actual existence, but which also exists only if, and in the way that, this particular does.) This confirms what we learned from our discussion of Spinoza's substance-monism (2.2), namely that we must rule out any interpretations of Spinoza's metaphysics of essence on which he would allow only for species-essences. Furthermore, we have not been able to determine yet whether Spinoza in fact recognizes other kinds of essences in addition to the unique essences of formally-real particulars. But the fact that Spinoza holds that only particulars have formal reality (2.6) does rule out as a possible interpretation of his position any sort of Platonism on which species-essences, were such to be admitted, could have formal reality independently of particulars.

This then is the little more we now know about Spinozistic essences. However there is an additional conclusion that we are also now in a position to draw, one that has to do not with essences per se but rather with our representations of them. It is this. It's clear that on Spinoza's account finite minds cannot avoid forming inadequate imaginative general ideas. (This is because the fundamental intentional object of any mind is the corresponding 'body' [E2p13]. But every such body is finite [E2def1], and constantly acted on by other bodies [E4p18s (II/222); E1p28]. Inevitably, the images a body receives become overlaid and confused.) However nothing we have seen thus far forces us to conclude that in Spinoza's view it would be impossible to form general ideas in some other way than by relying on our inherently limited empirical imagination. ${ }^{44}$ And this leaves open the possibility that in addition to the empirically-grounded common notions (and whatever they imply), Spinoza may also allow for another kind (or kinds) of adequate general ideas, and thus perhaps also adequate ideas of species-essences.

At this point in our inquiry we are left then with two main loose threads. Namely, we have not determined yet whether Spinoza in fact admits into his framework either (i) adequate general notions other than common notions; or (ii) essences other than the unique essences of formally-real particulars. Answering these two questions will help us piece together the rest of Spinoza's doctrine of essence.

To find the two answers, it will be helpful to look at the evidence for the universalist interpretations of Spinoza's metaphysics, i.e. for interpretations on which Spinoza does indeed allow for species-essences. This will be the task of the next section.

\section{Spinoza as a universalist}

3.1 .

On universalist interpretations of his metaphysics, Spinoza is committed to the existence of more general species-essences. Prima facie, there is plenty 
of textual evidence for such a conclusion, in particular within Spinoza's moral philosophy. Consider for instance the following passages:

[T] he greatest good of those who seek virtue is to know God, i.e. ... a good that is common to all men, and can be possessed equally by all men insofar as they are of the same nature [omnibus hominibus quatenus ejusdem sunt naturae $]$... Schol .... [I]t is not by accident that man's greatest good is common to all; rather, it arises from the very nature of reason, because it is deduced from the very essence of man [humana essentia] (E4p36d,s).

Nothing can agree [convenire] more with the nature of any thing than other individuals of the same species [ejusdem speciei individua]. And so ... nothing is more useful to man in preserving his being and enjoying a rational life than a man who is guided by reason (E4AppIX).

Only insofar as men live according to the guidance of reason, must they always agree in nature [natura ... conveniunt $]$... [I]nsofar as men live according to the guidance of reason, they must do only those things that are good for human nature, and hence, for each man [humanae naturae et consequenter unicuique homini], i.e. ... those things that agree with the nature of each man $(\mathrm{E} 4 \mathrm{p} 35, \mathrm{~d}){ }^{45}$

Passages such as these seem to show quite unambiguously that according to Spinoza there are (in some yet-to-be-determined sense of 'being') speciesessences shared by distinct particulars. Not least there seems to be a common essence to being 'human', possessed by all particular humans, who thus 'agree' in their essential nature, even if they realize it to different degrees, corresponding to their degree of rationality. It is because our individual natures can 'agree' in this way that we can have a common good, be beneficial to one another, become one as a society, and an egoistic concern for self-preservation can be reconciled with altruism.

However, passages suggesting a universalist interpretation of 'essence' are not restricted to Spinoza's analyses of the human good, as in the examples above. The existence of such alternative sources is no trivial matter for the advocate of universalism. This is because the truth-aptness of Spinoza's moral doctrines is a matter of some controversy: many view these doctrines merely as pragmatic expedients or therapeutic fictions. ${ }^{46}$ Were Spinoza's references to species-essences restricted to an ethical context, we could thus doubt that Spinoza was committed to the existence of species such as 'human nature' in full metaphysical rigour. For we can easily imagine that for ethical or political ends it would be useful, even if strictly speaking false, to invoke the idea of a common human nature. So it is important that Spinoza refers to species-essences also in the context of doctrines that cannot plausibly be dismissed as merely therapeutic fictions.

Some of the passages in question still concern human nature specifically. For example, Spinoza asserts in Part 1 that two human beings 'can agree entirely according to their essence' such that 'if the essence of one could be destroyed, and become false [falsa], the other's essence would also be 
destroyed [NS: and become false]' (E1p17s[II]; II/63). He also writes that the 'being of substance does not pertain to the essence of man' because 'there are not two substances of the same nature [ejusdem naturae]' but 'a number of men [plures homines] can exist' $(\mathrm{E} 2 \mathrm{p} 10, \mathrm{~s}) .{ }^{47}$

Species-essences also appear in passages bearing generally on the generation and corruption of things, i.e. on their coming in and out of existence. Let me give two examples. First, Spinoza illustrates what it means for a thing to be 'changed from one essence, or [seu] form, to another' with the following example: 'a horse is destroyed [destruitur] as much if it is changed into a man as if it is changed into an insect' (E4Pref; II/208). Here, the essence whose change marks the destruction of the corresponding 'thing' is a species-essence - the essence of a 'horse', 'man', 'insect' - not the unique essence of a particular (of Bucephalus or Peter) ${ }^{48}$ Secondly, consider the notorious conclusion of the conatus doctrine that self-destruction on the grounds of essential properties alone is metaphysically impossible. For Spinoza this is a self-evident consequence of the fact that a thing's 'definition' only 'affirms' or 'posits' but does not 'deny' or 'take away' a thing's essence (E3p4d). What is often overlooked is that Spinoza wishes to rule out here not just the metaphysical possibility of genuine suicide, but equally the possibility of distinct particulars harming one another through an essential nature they have in common. As Spinoza puts this, 'if a thing were evil for us through what it has in common with us [nobiscum habet commune], then the thing could diminish or restrain what it has in common with us. But (by 3p4) this is absurd (E4p30d; my ital.). That is, for Spinoza it follows from E3p4 that insofar as Vladimir is essentially $F$, he cannot be harmed by Estragon insofar as the latter is also essentially $F$. For Spinoza to appeal to E3p4 in an analysis of causal interaction among distinct particulars means that he holds that such particulars can indeed share one and the same essence. ${ }^{49}$

\section{2 .}

There are then clear textual reasons to conclude that Spinoza is indeed committed to some sort of universalism about essences. For this follows not just from his claims about human nature specifically, but also from perfectly general theses regarding the corruption and generation of things. ${ }^{50}$ What remains to be determined is what sort of universalism to attribute to Spinoza.

The two principal constraints on the kind of answer we could offer to this question stem from our findings in Section 2: Spinoza's universalism must be reconcilable with (i) his commitment to the existence in nature of the unique essences of formally-real particulars, and with (ii) his belief that only particulars have formal reality. Consistently with these constraints, above (2.7) we have already ruled out interpretations on which only species-essences would 
exist as well as interpretations on which formally-real species-essences would exist independently of particulars.

A natural next question to ask is this: could Spinoza endorse a non-Platonizing kind of realism about species-essences on which the latter would exist, in a mind-independent manner, in the particulars, i.e. as their metaphysical constituents? ${ }^{51}$ This sort of realist reading meets both of the aforementioned constraints - i.e. both the requirement that (i) formallyreal particulars have unique essences (which could be understood, for instance, as further determinations of species-essences), and the requirement that (ii) only particulars have formal reality (insofar as the species-essences would not exist apart from, or independently of, the particulars). In favour of this realist proposal we could also note that we can easily construe in this realist vein the passages and doctrines cited in 3.1 as evidence for Spinoza's universalism, and bearing on the ways that things, including human beings, 'agree' or differ 'in nature', or have something 'in common'. However, we also have to grant that this realist interpretation of such passages is not their only possible interpretation. For all of them are equally amenable to a non-realist reading on which the species-essences in question would be mind-dependent, and have being only insofar as they are represented. Consider for example Spinoza's recurring description of things as 'agreeing in nature'. We can certainly interpret this locution realistically, i.e. as referring to an agreement in $r e .{ }^{52}$ On this construal of 'agreement', it is because one and the same species-essence is present as a metaphysical constituent in all particular spiders, for example, that all spiders could be said veridically to 'agree in nature'. However, we would be remiss if we did not acknowledge that this terminology of 'agreement' was also standardly used by medieval and modern nominalists and conceptualists to pick out similarities among particular things, recognized by a mind. ${ }^{53}$ On this non-realist construal of 'agreement', to say that certain particulars 'agree in nature' is just to say that they resemble one another in relation to some mind. But such similarities are not to be mistaken for a constitutive presence of something formally-real and identical in all particulars under consideration.

What I want to show in the next and final section of the article is that it is this non-realist construal of 'agreement' as a cognized similarity that puts us on the right track for understanding Spinoza's brand of universalism about essences. I will argue that we should see Spinoza as a 'constructivist', that is, as one who holds that the unique essences of formally-real particulars coexist with more general but mind-dependent species-essences, constructed by finite minds but grounded in actual, recognized similarities. I will argue that although my account is quite speculative, it fits best both with the textual evidence and with Spinoza's epistemology - in particular with his view of how we come to think by means of general notions in the first place. 


\section{Spinoza as a constructivist}

I will start with a preliminary sketch of what I understand by 'constructivism'. In 4.2 I will offer textual evidence for interpreting Spinoza along these lines. In 4.3 I will show how a constructivist reading of Spinoza illuminates doctrines whose interpretation earlier presented some difficulty. I will conclude in 4.4 with brief methodological remarks.

\section{1.}

We can introduce Spinoza's constructivism about essences by means of a two-'level' model of his ontology. The lower 'level' consists of what genuinely $i s$ - i.e. of 'real beings' with formal reality. It thus consists exclusively of concrete particulars - entities endowed with causal powers and incapable of existing in, or as a constituent of, many distinct things at the same time. Only such particulars - finite and infinite alike - are caused to actually exist by substance and hence have being independently of being thought of by any finite ${ }^{54}$ mind. All these particulars also possess unique and formally-real essences. Finally, the properties of the particulars (including the properties that make up their essences) are trope-like. However, the properties can resemble one other, to various degrees. This similarity genuinely obtains in re, independently of any finite mind's activity. ${ }^{55}$

The second 'level' of Spinoza's ontology consists of what has solely an ideal, i.e. mind-dependent, reality. ${ }^{56}$ This includes species-essences of various degrees of generality or determinateness (the essence of 'spider' as much as the essence of 'being'). The being or reality of these species-essences consists solely in being represented, i.e. in the temporary objective reality they possess as intentional objects of finite minds.

Level two is ontologically dependent on level one. This is insofar as species-essences can be said to be only insofar as they constitute ways that finite minds represent formally-real particulars. Finite minds spontaneously tend to compare the properties of particulars in abstraction from their other properties, and, as a result, come to think of these particulars as the same in some respect, forming representations of less determinate entities (e.g. 'animal'). ${ }^{57}$ General ideas formed this way will then refer distributively to the relevant particulars.

This is the constructivist model in its most basic outline. ${ }^{58}$ On this model, each formally-real particular in Spinoza's framework has a unique essence distinct from the essences of all other formally-real particulars. But any such particular can also be apprehended as having one or more general natures in common. (For example, Estragon can be apprehended not just in his unique essence, but also as a 'spider', an 'animal', and a 'being'.) So, contrary to accounts on which Spinoza simply rejects all universals (cf. 2.6), on the constructivist reading Spinoza does not deny that there are universals, nor that 
the ideas that refer to them can, under the right circumstances, be meaningful and well-founded in the properties of things (and perhaps even, as we shall see later, true). The constructivist account merely specifies what kind of being is proper to species-essences (not real but merely ideal being), and the grounds on which ideas representing such universals have meaning (the compared properties of formally-real particulars).

Another way to put the basic contention of the constructivist reading is that we should not treat Spinoza's ontology as if were limited to 'real beings': we need to take seriously the idea that a 'being of reason' is a type of being, and 'objective reality' a kind of reality. On the proposed interpretation, there are then two distinct but precisely related ways to 'be', or to be 'real', in Spinoza's metaphysics. Universals can be described as 'nothing' (CM1.1; $\mathrm{I} / 235$ ) only if we are counting what has mind-independent reality alone. But in metaphysical rigour they are not 'nothing' when we take the notion of 'reality' more broadly to include also objective reality. ${ }^{59}$

On this reading, whenever Spinoza himself employs general terms that do not name common notions or their consequences such terms will be taken to refer to beings endowed with objective reality alone. To return to passages cited in 3.1, it is arguably in reference to such constructed, merely ideal entities that Spinoza declares that if the essence of one human being becomes 'false', then so does the essence of another human being; that two individuals can 'agree entirely' in their natures; and finally that it is 'absurd' for a thing to be harmful to another through a nature they have 'in common'.

Let me now turn to the textual evidence for my interpretation. This will also allow me to flesh out the account further, in particular insofar as it allows for better and worse methods of construction of species-essences.

4.2.

We can represent the constructivist interpretation of Spinoza's metaphysics as making the following four main claims: (i) only particulars and their essences have formal reality; (ii) the essences of such actually-existing particulars are unique; however (iii) Spinoza's metaphysics also allows for more general species-essences; (iv) such species-essences are only insofar as they constitute ways that finite minds spontaneously think of certain genuinely similar particulars as the same in some respect, when they abstract and compare their properties. I take the first three claims to have already been established in Sections 2 and 3. In what follows I will focus on evidence for claim (iv).

Consider first Spinoza's division of 'things' in general into those that exist in 'nature' and artificial things - entia rationis - that exist only in the 'intellect': 
Some things [dingen] are in our intellect and not in Nature [in ons verstand ... niet in de Natuur]; so these are only our own work, and they help us to understand things distinctly [onderscheidelijk ... verstaan]. Among these we include all relations, which have reference to different things. These we call beings of reason [Entia Rationis] (KV1.10; I/49). ${ }^{60}$

Spinoza specifies further that ideas of things that have being only in the intellect (i) originate in our comparisons of particulars, and (ii) refer only to those particulars:

From the fact that we compare things with one another [res inter se comparamus] certain notions arise [oriuntur] which nevertheless are nothing outside the things themselves [extra res ipsas] but modes of thinking. This is clear from the fact that if we wish to consider them as things posited outside of thought, we immediately render confused the clear concept which we otherwise have of them. These are such notions as Opposition, Order, Agreement, Difference, Subject, Adjunct ... We perceive them clearly enough I say insofar as we conceive them not as something different [diversum] from the essences of the things opposed, ordered, etc., but only as modes of thinking by which we retain or imagine the things themselves more easily (CM1.5; 1/245; my ital.). ${ }^{61}$

The next sort of textual evidence I want to point to is the fact that Spinoza repeatedly associates 'universality' and 'abstraction', where the latter is understood as selective attention (e.g. TIE[57]; E4p62s [II/257]; E2p49s [II/135]). This suggests that the representation of at least some universals requires in his view the mental act of abstraction. ${ }^{62}$ (This is in contrast to the universality of common notions, which is secured by the strict identity in re of the properties represented by such notions.) He also seems to regard the existence of a perceived similarity as a necessary condition for forming such abstract universal ideas: the unique 'origin of Nature', he writes, can by contrast never be 'conceived abstractly, or universally [abstracte sive universaliter]' 'since it has no likeness [similitudinem]' to other, 'changeable things' (TIE[76]). ${ }^{63}$

Further evidence for the constructivist account can be found in Spinoza's treatment of the will. It is well known that Spinoza denies the existence of anything like a 'faculty' of will, over and above particular affirmations and negations (E2p49d). What is less often noted is that this is because for him the will represents an ens rationis, constructed from our representations of particular affirmations and negations. As Spinoza explains in an early letter, the "will differs from this or that volition in the same way as whiteness differs from this or that white thing, or humanity differs from this or that man ... [T] he will, then, is only a being of reason' (Ep.2; I/9). He develops this account in more detail in the Ethics:

... will is something universal, which is predicated of all ideas, and which signifies only what is common to all ideas [voluntas universale quid sit quod de omnibus ideis praedicatur quodque id tantum significat quod omnibus ideis commune est], viz. the affirmation, whose adequate essence, 
therefore, insofar as it is thus conceived abstractly [abstracte], must be in ${ }^{64}$ each idea, and in this way only must be the same in all [debet esse in unaquaque idea et hac ratione tantum in omnibus eadem], but not insofar as it is considered to constitute the idea's essence; for in that regard the singular affirmations differ (E2p49s[IIIB(iii)]; II/135; my ital.).

Spinoza's point in this passage is that although particular, formally-real affirmations (ideas) are all unique (and hence, we can add, will at most resemble one another), we can nonetheless view them as the same if, and only if, we view them abstractly, namely solely as instances of affirmation. The idea of a 'will' represents just this abstract universal, 'affirmation'.

Spinoza concludes that faculties like the will,

... are either complete fictions or nothing but Metaphysical beings or universals, which we are used to forming from particulars [fictias vel ... entia metaphysica vel universalia quae ex particularibus formare solemus]. So intellect and will are to this or that idea, or to this or that volition as 'stone-ness' is to this or that stone, or man to Peter or Paul .... [T] hese faculties are universal notions which are not distinguished [distinguuntur] from the singulars from which we form them [singularibus ex quibus easdem formamus] (E2p48s; II/129-30; my ital.). ${ }^{65}$

The upshot of this passage is that if entities such as 'will' and 'man' are not to be mere chimeras, nor questionable entities admitted by earlier metaphysicians, ${ }^{66}$ they must be traced back to our mental acts and grounded in formally-real particulars. It is we who form universal notions representing entities such as 'will' and 'man', on the basis of our ideas of particulars. In consequence, such entities cannot be regarded as genuinely distinct from the relevant particulars. This, I suggest, is both in the sense that such universals do not possess any formal reality in themselves, and in the sense that the ideas representing them refer distributively just to the particulars.

The passage also hints at the fact that we have something like a tendency to apprehend being through general notions, or a mental habit of thinking in this way. (As Spinoza puts it, we are 'used to' forming such ideas). This element of his view is further clarified by his remark that our minds 'immediately' form abstract general ideas: 'the reason why these modes of thinking ['beings of reason'] are taken for ideas of things is that they arise from the ideas of real beings so immediately [immediate] that they are quite easily confused with them' (CM1.1; I/234; my ital.). ${ }^{67}$ I suggest that Spinoza has in mind here something like an innate ability or a spontaneous tendency of finite minds to abstract, compare, and generalize. (Hence the need, discussed in 2.6, to warn us about the dangers of confusing the real and the ideal.) In contrast to moderns like Hume for example, this is not a property of minds on which Spinoza elaborates at great length. However, its operation seems to be implicit in some of his other discussions of how we represent being. For example, presumably it is precisely because we are innately inclined to compare that, once we think in general terms, we tend to generate 
further normative representations on that basis, as when we regard certain particulars as more or less 'perfect' in their kind (E4Pref; II/207-8). ${ }^{68}$

\section{3 .}

With this I take myself to have textually substantiated the key theses of the constructivist reading of Spinoza's metaphysics of essence. What I would like to do now is demonstrate how this reading illuminates doctrines encountered earlier, whose interpretation presented some difficulty.

\subsection{1.}

First, and most obviously, the constructivist reading resolves the basic problem with which we began: that of an apparent equivocation in Spinoza's use of the term 'essence', which seems to shift between universal and particular senses. The constructivist model dispels this appearance of inconsistency by showing that Spinoza's metaphysics allows for two different kinds of essences.

The second doctrine I want to return to is Spinoza's definition of essence. In 2.5 I argued that, on its own, E2def2 does not specify at what level of generality we should locate the 'essences' and 'things' figuring in that definition. From a constructivist perspective, this reflects not an ambiguity in Spinoza's formulation, but the fact that his metaphysics requires a definition of 'essence' that can be applied to both particular and general essences.

Spinoza's conatus doctrine (2.3) seemed to be plagued by a similar difficulty as E2def2, and receives an analogous solution. The difficulty, we can recall, is that Spinoza's talk of striving in 'one's being' can refer not just to the being unique to the striving particular (as many readers assume), but also to its being qua member of a kind. Given a constructivist account of essence, the conatus doctrine will dictate both that all particulars in nature strive in their distinctive being (i.e. that they produce the formally-real effects that are the necessary consequences of their unique essences), and that we can also apprehend these particulars as striving in the being they share with others of the same kind (and so understand them to be producing certain effects qua 'spiders' or 'animals' for example).

Recall next Spinoza's doctrine of scientia intuitiva. In 2.4 we reached the tentative conclusion that Spinoza holds that at least sometimes what we know in intuition are species-essences (for example, the essence of the 'human mind'). The constructivist account requires us to refine this conclusion. This is because on that account species-essences are just ways of conceiving of and referring distributively to particulars. So even in cases of intuitive knowledge of universals (such as 'human mind'), ultimately it will still be particulars that will constitute the proper object of this knowledge. 
Finally, recall my suggestion (2.7) that nothing about Spinoza's criticisms of imaginative universals in E2p40s1, nor about his warnings against confusing real and ideal entities, dictates that in his view it would be impossible for finite minds to form adequate general notions (other than common notions) in some other way than by relying on our inherently limited imagination. We are now in a position to flesh out this suggestion, as follows:

We should note first of all that we cannot infer simply from the ideality of species-essences that the ideas representing them will be necessarily inadequate. ${ }^{69}$ To do so would be to confuse mind-dependence with mere illusion, a distinction that many moderns (not least Leibniz, Berkeley, and Kant) took great care to maintain.

Moreover, the standard conclusion that Spinoza simply condemns all such ideas (cf. 2.7) fails to recognize that according to Spinoza there are better and worse ways so to speak to construct general ideas. This is precisely one of the differences between 'first' and 'second' kinds of cognition in the Ethics: these represent, inter alia, two different ways we 'form universal notions [notiones universales formare]' (E2p40s2; II/122). ${ }^{70}$ The universal notions that belong to the first kind of cognition are the empirically-formed imaginative notions that we saw Spinoza denounce in E2p40s1 as capable of representing distinctly only the relative properties of arbitrary collections of things. In contrast, to exercise 'reason [ratio]' - which unlike imagination is invariably adequate - is to 'form universal notions' from common notions and 'adequate ideas of the properties [proprietatum] of things' (ibid.). In short, for Spinoza reasoning is a causal process not merely grounded in adequate general notions - as is often (and rightly) emphasized, with an eye to common notions - but also consisting in actively forming further adequate general notions. These further general notions constitutive of 'reasoning' will be necessarily adequate, since adequate ideas can give raise only to other adequate ideas (E2p40).

This much can be established by and large simply by looking at the text of the Ethics. But now I'd like to make a further, more speculative, suggestion. This is that in addition to any ideas inferable from common notions alone, among the further adequate general notions constitutive of reasoning we will also find the non-imaginative, adequate universal notions whose possibility was broached above (2.7). Where common notions represent formally-real and either universally- or at least pervasively-instantiated properties of things, these adequate universal notions will instead represent mind-dependent universals, constructed on the basis of 'adequate ideas of the properties of things' - and more precisely, on the basis of adequately-conceived properties that render the essences of particulars similar. ${ }^{71}$ That is, where imaginative general notions represent, as we saw (2.6), species-essences constructed on the basis of properties that bodies 'agree in' merely insofar as 
they affect the perceiver's body (E2p40s1), rational universal notions will be formed on the basis of an adequate knowledge of the essential properties of particulars, and the recognition that some of these essential properties genuinely do resemble ('agree' with) one another. ${ }^{72}$ In other words, the principal difference between adequate and inadequate representations of universals will be that where the latter representations are constructed on the basis of idiosyncratic sets of relative properties of things, the former require us first to adequately cognize the unique essences of particulars, and actual similarities among such essences. As Spinoza writes, 'We perceive [abstract notions like 'Opposition' and 'Order'] clearly enough ... insofar as we conceive them not as something different from the essences of the things opposed, ordered, etc.'(CM1.5; 1/245; my ital.).

An example may be helpful here. Let's assume - plausibly - that for Spinoza being 'human', understood rationally and adequately, means essentially having the power to reason $(\mathrm{E} 4 \mathrm{p} 35 \mathrm{c} 1-36 \mathrm{~s}) .^{73}$ On the account I am attributing to Spinoza, this means that all particulars rationally represented and classified as 'human' are in fact similar in essentially having the power to reason (i.e. the power to produce certain kinds of ideas). In contrast, Spinoza explicitly rejects as inadequate accounts that define a 'human being' as a 'featherless biped' and as a being 'having erect stature' (E2p40s1; II/120-1).$^{74}$ On the interpretation being proposed, these accounts of human nature fail because the properties of bipedalism and featherlessness do not in Spinoza's eyes represent the essential properties of particulars rationally classifiable as 'human', even if arguably both bipedalism and featherlessness are (non-essential) properties that do render such particulars similar.

In short, on the account of universal notions I am proposing, Spinoza's epistemology has room for rational and adequate representations of minddependent - 'constructed' - universals in addition to common notions. Since beings of reason 'explain a thing by determining it through comparison with another' (CM1.1; I/234), such rational representations of universals would allow us to rationally and adequately determine the natures of particulars in thought by subsuming them under such universals. These adequate general notions fit well Spinoza's description of modes of thinking that arise from acts of comparison but are nonetheless 'clear concept[s]' (CM1.5; 1/ 245 ) and help us to 'understand' 'distinctly' (KV1.10; I/49). ${ }^{75}$ To borrow a Leibnizian locution, such rational universal notions could be described as 'well-founded': despite their abstract nature and the ideality of the objects they represent, they are grounded in adequate representations of the essences of formally-real particulars.

Indeed, arguably Spinoza regards such rational general notions not merely as clear, distinct and well-founded but also as true ${ }^{76}$ This is suggested by his repeated description of 'abstractions' as 'true' (e.g. in his claim that we can have 'true' but 'abstract, or [sive] universal' knowledge of 'good and evil' $[\mathrm{E} 4 \mathrm{p} 62 \mathrm{~s}])^{77}$; as well as by Ep.9, which has often been read as implying that 
Spinoza regards his own definitions as true (I/42-3). His definitions often take for their object universals not representable by common notions. (Consider for example, definitions of 'adequate idea', 'adequate cause', and 'affect': their definienda are neither unique particulars nor omnipresent or pervasive properties nor, arguably, simple consequences of such.) ${ }^{78}$

If we accept this reading of Spinoza's view of universals and general notions, Spinoza's doctrine of common notions no longer appears as an ad hoc concession in the course of giving up on universal notions generally. Rather, common notions can now be seen as only one element within a more comprehensive rehabilitation of general notions. As we have seen, for Spinoza the true epistemic danger lies not in universals per se, but rather in inadequate universals, and in misunderstanding the nature of universals more generally (as when we assume that all universals exist in re in a mind-independent manner, and can be known adequately through the senses).

4.4 .

Let me conclude with three brief methodological comments.

First, my aim in this article is to argue that a certain view of essences and universals is Spinoza's. It is not to defend these views, in all their detail, on Spinoza's behalf. There are all-too-familiar difficulties awaiting someone who proposes a qualitative resemblance that does not already tacitly draw on universality, and does not generate a vicious regress of resemblances. ${ }^{79}$ But these difficulties aren't particular to Spinoza. Nor are views like his lacking in defenders. ${ }^{80}$ So I do not believe that these difficulties should prevent us from seeing the position I have attributed to Spinoza as interesting, plausible and arguably coherent.

Second, the view I have outlined could have perhaps been labelled a 'nominalist' one. ${ }^{81} \mathrm{I}$ have deliberately avoided using this term. This is not just to minimize the probability of importing foreign and misleading associations, but primarily because the label 'nominalism' has already been used in the context of Spinoza's philosophy in so many different ways ${ }^{82}$ that relying on it would likely only further obscure matters.

Finally, I readily admit that my reading of Spinoza is a speculative one even if it is also in line with what other non-realist early moderns thought about real existents, similarity among particulars, and mind-dependence of universals. ${ }^{83}$ It is also true that the position I've attributed to Spinoza is not as precise as one would wish at key conceptual turns (for example, in its account of the nature of the transition from recognizing the similarity of things' properties to postulating that these things are the same). But Spinoza simply does not discuss the relevant issues at sufficient length, or with sufficient systematicity. So if as interpreters we wish to retain a respectable degree of textual fidelity, rather than engaging in textually unmoored speculation, such details might have to remain only vaguely sketched. What I have 
tried to argue is that the constructivist account puts together the scattered and incomplete puzzle of Spinoza's various claims and doctrines better than other interpretations. ${ }^{84}$

\section{NOTES}

1 For the equivalence see e.g. E1p36d; E4def8; E4p19d.In this article I rely on both early and late works of Spinoza (see (Spinoza, 1925; Spinoza, 1984; Spinoza, 1995)). I believe that the relevant views remain largely unchanged. I try to demonstrate this continuity in the article, and to flag discrepancies. I use Curley's translation unless otherwise noted.

2 The sense in which things are distinct for Spinoza changes; in the $K V$ and Ethics real distinction is replaced by a modal one.

3 For nominalist readings of Spinoza see (Bennett, 1984), \$\$11.2, 69.4; (Donagan, 1973), p. 51; (Friedman, 1978), pp. 89-90; (Rice, 1994), pp. 19, 26. For Platonic readings, (Haserot, 1950), pp. 479-80. For the claim that Spinozistic essences are particular, (Donagan, 1973), p. 51; (Della Rocca, 2008), p. 94; (Matson, 1990), p. 88; (Garrett, 1999), p. 325; (Crane \& Sandler, 2005), p. 194. For the claim that they are universal, (Bennett, 1984), §69.4; (Garrett, 2010), pp. 13, 108, 111; cf. (Wilson, 1999), p. 345.

4 Unless further restricted, 'particularism' as I understand it does not stipulate that only such unique essences of particulars exist.

5 (Della Rocca, 2004), p. 132, 1996, p. 87; cf. (Curley, 1988), pp. 11-2; (Gueroult, 1968/ 1974), p. 548.

6 With the exception of (Martin, 2008).

7 For Spinoza's use of this Scholastic and Cartesian distinction cf. E1p17s[II]; E2p7c; TIE [33-5, 41-2].

8 See e.g. (Leibniz, 1996), New Essays 3.6. Some medieval thinkers also hold that a given nature can exist as one as a universal in the intellect, but as many in the particulars materially individuating this universal.

9 TIE[93, 95], E1p8s2 (II/50). For the sake of simplicity, in what follows I will understand 'species-essence' to exclude the lowest (individual) species.

10 In the Curley translation, 'NS' refers to the posthumous 1677 Dutch edition of Spinoza's writings.

11 Cf. (Bennett, 1984). On particularist readings, properties constituting essence will have to be trope-like. A cluster or bundle of such properties - perhaps one that is functionally unified, as a Spinozistic 'individual' is (cf. E2def[8]) - could then constitute a unique essence.For a reading of Spinoza in terms of trope theory see (Melamed, 2009); (Newlands, 2010), p. 3. For a contemporary view that relies on a distinction between essential and non-essential tropes see e.g. (Simons, 1994).

12 E2p8c,s; E2p45s; E5p29s. On formal versus actual essences, see e.g. (Schmaltz, 1997). When this givenness is a matter of actual existence, Spinoza glosses 'essence' as 'power [potentia]'. So the 'actual essence' of any thing - i.e. the essence of any formally-real, actually existing thing - consists in its power to persevere in existence and produce effects (E3p7; cf. E1p34; E3DefAff1). Spinoza also identifies 'power' with being the sufficient cause of an effect (CM2.12; I/280). Arguably then, for any formally-real, actually existing thing, its essence is just the causal power necessary and sufficient for it to exist and produce certain effects. On Spinozistic essence as power, see e.g. (Viljanen, 2011).

13 But see (Bennett, 1984), §69.4.

14 More precisely, given Spinoza's view that the essence of substance expresses itself under 'infinite' attributes, it is each of the conceptually-distinct essences of substance under various attributes that is necessarily unique. I will not enter here into the controversy over the relation of 
the essence of God qua absolutely infinite to substantial essences under each attribute, nor into the nature of the distinction between the attributes themselves. But see e.g. (Donagan, 1973); (Deleuze, 1990).

15 (Steinberg, 1987), p. 190 n6; (Martin, 2008), pp. 491-2; (Della Rocca, 2004), p. 133; cf. (Garber, 2004), p. 189; (Garrett, 1999), p. 325.

16 Typically, the doctrine is limited to finite modes, but for a broader reading see (Della Rocca, 2004), pp. 152-3; (Hübner, 2014a).

17 For fuller treatments of Descartes's view, see e.g. (Brown, 2011); (Hoffman, 2002).

18 For a defence of this reading of the conatus doctrine, see (Hübner, 2014a).

19 As Garrett (Garrett, 2010) notes, there is a strange redundancy in Spinoza's formulation, insofar as Spinoza talks about the essence of an attribute. I must skip over this difficulty here; I will treat the passage as if Spinoza had written simply 'essence of substance' (cf. E5p36s; II/303).

20 See e.g. (Bennett, 1984), §83.3-4; (Della Rocca, 1996), p. 86; (Gueroult, 1968/1974), p. 417; (Miller, 2003), pp. 130-1; cf. (Garrett, 2010), p. 110, n23; (Carr, 1978), pp. 242-3.We established in 2.2. that the essences that form the 'ground' of this knowledge - the conceptually distinct essences of substance under different attributes - are necessarily unique.

21 Alternatively one could try to appeal here to historical precedent. For example, Duns Scotus understood intuition as knowledge of present particulars. But again the evidence of tradition is mixed. Aristotle for example held that we have intellectual intuition of first principles, including mathematical principles, at least some of which are universal and generic (cf. e.g. (Aristotle, 1984), Post An. I.2-3; see (Duns Scotus, 1988)). Descartes uses 'intuition' in a similar way in Regulae III (see (Descartes, 1985), (Descartes, 1974-86)).

22 Pace (Bennett, 1984), §83.3.

23 Cf. (Garrett, 2010), p. 108; (Matheron, 1986).

24 Cf. (Carr, 1978), p. 244.

25 Cf. TIE[23-4].

26 Cf. (Bennett, 1984), §83.3.

27 Cf. CM1.6 (1/245); 1.1 (I/234); (Gueroult, 1973); (Matheron, 1986), p. 146; (Melamed, 2000); (Schliesser, 2014).

28 The CM passage describes both 'things' and 'discrete quantity' as being explained by number. I suggest that Spinoza's point is that (1) we explain things with number insofar as we determine collections of particulars with the help of numbers; (2) the notion of 'discrete quantity' is explained by number insofar as it can be further determined as a specific quantity with the help of numbers.

29 Cf. 'the universal is said equally of one, a great many, or infinitely many individuals' (E2p49sIIIB(i, iii); II/134-5).

30 For example, (Steinberg, 1987), pp. 190-1; (Bennett, 1984), §16.2; (Koistinen, 1991), pp. 13-4; (Della Rocca, 2004), p. 133; (Yovel, 1992), p. 163; (Martin, 2008), p. 492; cf. (Garrett, 2002), p. 152 n5.

31 Cf. (Della Rocca, 1996), p. 87. Della Rocca takes E2p37d to confirm this reading of E2def2 (2004, p. 133). But E2p37d asserts only that the essences of singular things cannot be general in the way that common notions are general; not that no essence is general.

32 Cf. TIE[75].

33 Cf. Ep.19 (I/90); KV1.6-7, 10 (I/43, 46, 49).

34 (Wilson, 1996), p. 114; (Curley, 1973), p. 357; (Pollock, 1880), pp. 150-1; (Savan, 1958), p. 217; (Melamed, 2000), pp. 9, 11, cf. 2009, p. 75; (Matson, 1990), p. 87; cf. (Bennett, 1984), §11.3; (Schliesser, 2014).

35 Common notions do not by themselves undermine particularism, since the properties they represent do not constitute the essence of any finite particular (E2p37).

36 Cf. Wilson's description of Spinoza's claim that 'knowledge of the second kind ... is ... a way of forming 'universal notions': yet it is based on the common notions' as a 'catch' (1996, p. 117). 
37 For example, (Matson, 1990), p. 87.

38 Of course, Spinoza's German and British Idealist readers will contest Spinoza's right to the claim that a multiplicity of distinct particulars exists, insofar as in their view he never adequately demonstrates the necessity of distinct modes (see e.g. (Hegel, 1995)); for discussion see (Melamed, 2010); (Newlands, 2011); (Hübner, 2015).

39 Presumably 'affirmative' at least in the sense that they involve no negation or differentiation in relation to a higher genus.

40 Cf. E2p49s[III.B.(iii)] (II/135); CM1.1 (I/235).

41 Cf. (Bennett, 1984), §11.2; (Haserot, 1950), p. 478; (Friedman, 1978), p. 89.Wilson chastises Spinoza for 'not bother[ing] to defend this account [in E2p40s1] against ... traditional rival theories of universals' (1996, p. 113), but this works as a criticism only if Spinoza's intention was to undermine all theories of universals; yet there is no evidence for that supposition.

42 Cf. (Locke, 1979), III.iii.2. The processes behind the formation of imaginative universals and imaginative transcendentals differ presumably at least in the degree of generality of resulting concepts (cf. (Melamed, 2000), p. 12).

43 Della Rocca (Della Rocca, 2004) offers a further argument for particularism. He claims that universalism is incompatible with Spinoza's 'identif[ication]' or 'conflati[on]' of 'thing' and its 'essence': if all human beings for example were to have the same essence then they would also be identical as things. However the argument fails because the evidence Della Rocca offers for Spinoza's identification of 'thing' and 'essence' doesn't withstand scrutiny. Della Rocca cites E4p31d, which states that failure to preserve one's 'nature' contradicts the thesis of universal preservation of one's 'being'. But it is not clear why we cannot read 'nature' and 'being' here as co-referential, or why either of these two terms should be identified with 'thing'. As further evidence Della Rocca writes that Spinoza equivocates between (1) what constitutes a mind and (2) what constitutes the essence of a mind. However, the proposition that Della Rocca cites as example of (1) in fact discusses 'the first thing that constitutes the actual being' of a mind (E2p11; my ital.), i.e. presumably precisely the essence of mind, as what has to be given for the mind to be given. Della Rocca's last piece of evidence is E1p16c1-c2 where Spinoza moves from 'perceiving the nature of body' to 'having idea of body'. But again this can be read as implying that perceiving the essence of $\mathrm{x}$ is sufficient for having an idea of $\mathrm{x}$, not that $\mathrm{x}$ and its essence are the same.

44 Indeed, arguably Spinoza's very charge in E2p40s1 that imaginative general notions fail to reflect the true 'number', 'colour' and 'size' of particulars implies that it must be possible to have a more adequate understanding of such universals, in addition to common notions. Common notions cannot provide the perspective from which such criticism can be made at least because 'number' and 'size' for example are entia rationis.

45 Cf. E4p37s1 (II/236), E4p18s (II/223). See (Hübner, 2014b), for an account of Spinoza's view of human nature.Though Spinoza often treats essentia and natura interchangeably, natura dominates in the moral-philosophical context, arguably signalling Spinoza's association of that word with mind-dependent contexts, in contrast to formally-real 'essences'.

46 For example, (Carriero, 1995), p. 272; (Garrett, 1996), pp. 288-9.

47 Cf. KV2pref (I/53).

48 Pace (Garrett, 2002), p. 152 n5.

49 Cf. E4p35-37.

50 Here are three arguments for universalism that do not withstand scrutiny:First, Spinoza's claim that 'no definition involves or expresses any certain number of individuals, since it expresses nothing other than the nature of the thing defined' (E1p8s2; II/50), could be taken to imply that all definitions are of universal natures. But Spinoza's definition of God is a clear counter-example. So the point of E1p8s2 must be instead that a definition alone doesn't suffice to determine the number of instances of a given nature.Haserot suggests that Spinoza's talk of 'true ideas of modifications which do not exist' (E1p8s2) shows a commitment to species-essences (1950, p. 479). Presumably the thought is that these nonexistent modes are unactualized instances of universals. But the scholium doesn't require 
this reading; its point is rather that we can conceive of the essences of nonexistent things on the basis of ideas of other things.A third argument appeals to Spinoza's doctrine of mind eternity. The claim is that if minds outside duration no longer retain distinguishing personal markers of memory and imagination, such minds are reduced to 'the essence of the[ir] kind' ((Martin, 2008), p. 493). But this doesn't follow: outside duration particular minds can be distinguished qua unique sets of adequate ideas. (The number of distinct individuals might then be smaller than in duration.)

51 I understand this to exclude accounts on which there is merely a 'formal' or 'rational' distinction between the species-essence and the particular.

52 Cf. (Haserot, 1950), p. 480.

53 Cf. e.g. (Locke, 1979), III.iii.12; (Ockham, 1990), Ordinatio I dist.2, q.6.

54 The substantial infinite intellect is a necessary consequence of substantial essence. In this sense no particular exists unless also this intellect exists.

55 Given Spinoza's commitment to PSR, this resemblance cannot be a primitive or inexplicable fact, as it is for some other non-realists. At the very least we can say that the similar properties of particulars follow necessarily from the essence of substance.

56 Cf. Suárez's definition of ens rationis as what 'has being only objectively in the intellect' ((Suárez, 1995), DM54.1.6).

57 The essence of such a less determinate entity will presumably consist in the property (or properties) that allow this mind to regard the particulars in question abstractly as essentially the same (for example, eight-leggedness and venomousness). Any 'species' will then represent collections of particulars with a maximal degree of finitely-cognizable resemblance.

58 So I agree with Carriero (Carriero, 2005) that Spinoza distances himself from the Aristotelian picture on which species form part of the metaphysical constitution of the individual, and dictate how things ought to be, and that for Spinoza the formation of general ideas is a matter of us making comparisons on the basis of real similarities. But unlike me Carriero sees Spinoza's general ideas as 'not grounded in the constitution of the individual system [of matter]' (my ital.), and treats them merely as a 'pragmatic' question of us 'develop[ing] views about how things usually go' with systems that 'strike us as reasonably similar'.

59 Compare Spinoza's own broad sense of 'being' at E4Pref (II/207) with the narrower sense, equivalent to real being, at CM1.1 (I/235). I suggest that this earlier, narrower sense is rejected by the Ethics.

60 Cf. TIE[93,99], Ep.12 (I/58), Ep.83, CM.1.1 (I/234).

${ }^{61}$ Cf. CM2.7 (I/262); (Hobbes, 2004), De Corpore 19-20.

62 Spinoza also associates 'abstraction' with changing 'substantives ... into adjectives' (TIE [97]). Arguably this is because nouns can identify particulars, whereas adjectives are predicable of many things.

63 Cf. also Spinoza's assertion that the universal 'Unity' is 'only a mode of thinking by which we separate [separamus] the thing from others which are like [similes] it or agree with it in some way [aliquo modo conveniunt]' (CM1.6; 1/245). Cf. Descartes Pr1.59 (AT 8A.27).I don't think there is any decisive textual evidence for attributing to Spinoza the view that species-essences are merely a mind's actualization of what is already formally- or rationally-distinct in particulars. However, some passages (e.g. CM2.7; I/262) are amenable to such a reading.

64 The sense in which universals are 'in' particulars is, it seems, just insofar as the former are predicable of the latter. This sense of being-in would be distinct from the ontological relation of inherence (of modes and substance in substance).

65 Cf. CM1.6; I/247.

66 For this pejorative sense of 'metaphysics' as what has been thought by earlier metaphysicians cf. CM, passim. Presumably an ens metaphysicum is to be understood here also as distinct from an ens naturale insofar as it transcends the natural or empirically-knowable order. Cf. (Leibniz, 1969), p. 158. (Thanks to Martin Pickavé for discussion.)

${ }^{67}$ Cf. E1p15s[V] (II/59). 
68 A natural worry may arise here: is this tendency to apprehend being in general terms a brute fact about finite minds, potentially violating Spinoza's commitment to the PSR? Unlike the power to affirm, a tendency to generalize cannot be a property of all thought, and hence more or less immediately grounded in its essence, which in turn is conceivable per se (E1def3, Eldef4). For, as we saw earlier (2.6), universals seem to be the province of finite minds alone. I suggest that Spinoza can ground this tendency in the finitude of our bodies: insofar as we cannot avoid representing the body, and cannot prevent the gradual superimposition of bodily images, we also cannot avoid forming general ideas. But the fact that only finite minds represent with the help of general notions seems to present a prima facie counterexample to Spinoza's naturalism, which dictates that there can only be differences of degree in the laws governing substance and laws governing finite things(E3pref; II/138). I will not pursue this further here.

69 Pace (Melamed, 2000), pp. 15, 21. For further discussion of the difference between ideality and illusion in Spinoza see (Hübner, 2015).

70 Cf. (Bennett, 1984), §83.3. Arguably this distinction is presaged by CM's distinction between entia rationis that 'explain' things, and those that merely help 'imagine' or 'retain' them $(1.1 ; \mathrm{I} / 234)$. But in CM Spinoza still seems undecided about the epistemic value of entia rationis.

71 Of course there are other ways one could interpret what Spinoza means by 'adequate ideas of properties' in E2p40s2: these could be also (i) ideas inferred from common notions, discussed in E2p40 or (ii) what I have classified as the second type of common notion - notions of properties pervasive within a relevant causal environment (E2p39).

72 This does not mean that intuitive knowledge is necessarily a prerequisite of such rational knowledge: unlike in scientia intuitiva, this knowledge of essences does not stipulate that these essences must be deduced from the essences of the attributes.

73 See (Hübner, 2014b), for a fuller account.

74 At the time of Ep.12 Spinoza does not distinguish imaginative and rational abstraction, identifying beings of reason with beings of imagination (I/56-8). I think that this letter (despite its fame) should be seen as expressing an early, and partially abandoned, view of abstraction and beings of reason. Spinoza rewrites the relevant passages in E1p15s[V] (II/59). As rewritten, his point is only to show the superiority of intellectual conceptions of substantial 'quantity' over imaginative abstractions of the same. The scholium no longer identifies beings of reason with beings of imagination; it also does not show that all abstraction is inadequate (pace (Gueroult, 1973), pp. 198-9; (Melamed, 2000); (Schliesser, 2014), all of whom take Ep.12 and E1p15s to express the same position). It's plausible that for Spinoza certain general notions - e.g. 'quantity' and 'measure' (but not 'number', 'unity', or 'figure') - can only ever be imaginative, never rational, abstractions, since it is their nature to have empirical application. This, in addition to the scholium's narrow, polemical objective of undermining certain conceptions of God, might help explain why Spinoza talks only about imaginative abstraction in E1p15s.

75 Cf. also CM1.5 (1/245).

76 Pace Gueroult (Gueroult, 1973); and Haserot (Haserot, 1950) who takes 'entia rationis' to help us 'conjecture a reality that, in its true nature, lies beyond our ken'.In CM1.1 (I/235) Spinoza writes that truth and falsity do not pertain to entia rationis. This latter claim, like the expansion of the sense of 'being' (see note 59), represents in my view a shift in his position.

77 See TIE[57, 75]. Pace Curley, who doubts the authenticity of 'verae' in TIE\$57 (editorial note 44). Cf. also Spinoza's description of our abstract representations of the will as having an "adequate essence" (E2p49s[IIIB(iii)]; II/135).

78 Since 'truth' is an idea's 'agreement' with 'its object' (E1ax6), propositions involving rational universals will presumably be true if the predicate in question 'agrees' with the abstract nature to which it is being attributed (e.g. 'venomous' with 'spider').

79 See e.g. (Daly, 1997), p. 150.

$80 \quad$ See e.g. (Campbell, 1990), p. 37; (Oliver, 1996), p. 37.

81 Ockham comes to mind especially.

82 See note 3 . 
83 See e.g. (Locke, 1979), III.iii.9, 11-13; (Descartes, 1985), Pr1.58-9; (Hobbes, 2004), Leviathan 21, De Corpore 19-20; (Gassendi, 1972), Exercitationes, 43-5.

84 Many thanks to Donald Ainslie, Michael Della Rocca, Steve Nadler, Dominik Perler, Martin Pickavé, Marleen Rozemond, Clinton Tolley, anonymous reviewers, and audiences at Queen's and Simon Fraser Universities for invaluable comments on earlier drafts of this article.

\section{Department of Philosophy}

University of Toronto

\section{REFERENCES}

Aristotle (1984). The Complete Works of Aristotle, (ed.) J. Barnes. Princeton, NJ: Princeton University Press.

Bennett, J. (1984). A Study of Spinoza's Ethics. Indianapolis, IN: Hackett.

Brown, D. (2011). "The Duck's Leg: Descartes's Intermediate Distinction," Midwest Studies in Philosophy 35, pp. 26-45.

Campbell, K. (1990). Abstract Particulars. Oxford: Oxford University Press.

Carr, S. (1978). "Spinoza's Distinction Between Rational and Intuitive Knowledge," Philosophical Review 87(2), pp. 241-52.

Carriero, J. (1995). "On the Relationship Between Mode And Substance in Spinoza's Metaphysics,", Journal of the History of Philosophy 33(2), pp. 245-73.

Carriero, J. (2005). "Spinoza on final causality", in D. Garber and S. Nadler (eds) Oxford Studies in Early Modern Philosophy. Oxford: Oxford University Press, pp. 105-47.

Crane, J.K. and Sandler, R. (2005). "Identity and Distinction in Spinoza's Ethics", Pacific Philosophical Quarterly 86(2), pp. 188-200.

Curley, E. (1973). "Spinoza’s Moral Philosophy", in M. Grene (ed.) Spinoza: A Collection of Critical Essays. Garden City, NY: Anchor/Doubleday, pp. 354-76.

Curley, E. (1988). Behind the Geometrical Method. Princeton, NJ: Princeton University Press.

Daly, C. (1997). "Tropes", in D. H. Mellor and A. Oliver (eds) Properties. Oxford: Oxford University Press, pp. 140-59.

Deleuze, G. (1990). Expressionism in Philosophy: Spinoza, M. Joughin, trans. New York: Zone Books.

Della Rocca, M. (1996). Representation and the Mind-Body Problem. Oxford: Oxford University Press.

Della Rocca, M. (2004). "Egoism and the Imitation of Affects in Spinoza”, in Y. Yovel and G. Segal (eds) Spinoza on Reason and the Free Man. New York: Fordham University Press, pp. $123-43$.

Della Rocca, M. (2008). Spinoza. London and New York: Routledge.

Descartes, R. (1985). The Philosophical Writings of Descartes, ed. J. Cottingham, R. Stoothoff and D. Murdoch. Cambridge: Cambridge University Press.

Descartes, R. (1974-86). Oeuvres, ed. C. Adam and P. Tannery. Paris: Vrin/CNRS.

Donagan, A. (1973). "Essence and the Distinction of Attributes in Spinoza's Metaphysics", in Grene op. cit., pp. 164-81.

Duns Scotus, J. (1988). Philosophical Writings. Indianapolis, IN: Hackett.

Friedman, J. (1978). “An Overview of Spinoza's Ethics", Synthese 37, pp. 67-106.

Garber, D. (2004). "Dr. Fischelson's Dilemma: Spinoza on Freedom and Sociability", in Y. Yovel and G. Segal (eds) Spinoza on Reason and the Free Man. New York: Little Room Press, pp. 183-207. 
Garrett, D. (ed.) (1996). The Cambridge Companion to Spinoza. Cambridge: Cambridge University Press.

Garrett, D. (1999). "Teleology in Spinoza and Early Modern Rationalism", in R. Gennaro and C. Huenemann (eds) New Essays on the Rationalists. Oxford: Oxford University Press, pp. 310-35.

Garrett, D. (2002). "Spinoza's Conatus Argument”, in O. Koistinen and J. Biro (eds) Spinoza: Metaphysical Themes. Oxford: Oxford University Press, pp. 127-58.

Garrett, D. (2010). "Spinoza's Theory of scientia intuitiva", in T. Sorell et al. (eds) Scientia in Early Modern Philosophy. New York: Springer.

Gassendi, P. (1972). The Selected Works of Pierre Gassendi. New York: Johnson Reprint Co.

Gueroult, M. (1968/1974). Spinoza. Paris: Aubier-Montaigne.

Gueroult, M. (1973). "Spinoza's Letter on the Infinite", in Grene op. cit., pp. 182-212.

Haserot, F. (1950). "Spinoza and the Status of Universals", Philosophical Review 59(4), pp. 469-92.

Hegel, G.W.F. (1995). Lectures on the History of Philosophy, E. Haldane, trans. Lincoln, NE: University of Nebraska.

Hobbes, T. (2004). The English Works of Thomas Hobbes of Malmesbury, ed. W. Molesworth. London: Elibron Classics.

Hoffman, P. (2002). "Descartes' Theory of Distinctions", Philosophy and Phenomenological Research 64, pp. 57-78.

Hübner, K. (2014a). "Spinoza's Unorthodox Metaphysics of the Will”, in M. Della Rocca (ed.) The Oxford Handbook to Spinoza. Oxford: Oxford University Press.

Hübner, K. (2014b). "Spinoza on Being Human and Human Perfection", in A. Youpa and M. Kisner (eds) Essays on Spinoza's Ethical Theory. Oxford: Oxford University Press, pp. $124-42$.

Hübner, K. (2015). "Negation, Mind-Dependence and the Reality of the Finite in Spinoza", in Y. Melamed (ed.) The Early Spinoza. Oxford: Oxford University Press, pp. 221-37.

Koistinen, O. (1991). On the Metaphysics of Spinoza's Ethics. Turku: University of Turku.

Leibniz, G. (1969). Philosophical Papers and Letters, ed. L. Loemker. Dordrecht: Kluwer.

Leibniz, G. (1996). New Essays on Human Understanding, ed. P. Remnant and J. Bennett. Cambridge: Cambridge University Press.

Locke, J. (1979). An Essay Concerning Human Understanding, ed. P. Nidditch. Oxford: Oxford University Press.

Martin, C.P. (2008). "The Framework of Essences in Spinoza's Ethics", British Journal for the History of Philosophy 16(3), pp. 489-509.

Matheron, A. (1986). "Spinoza and Euclidean Arithmetic: The Example of the Fourth Proportional", in M. Grene and D. Nails (eds) Spinoza and the Sciences. Dordrecht: Reidel, pp. 125-50.

Matson, W. (1990). "Mind Essence and Body Eternity", in E. Curley and P-F. Moreau (eds) Spinoza: Issues and Directions. Leiden: Brill, pp. 82-95.

Melamed, Y. (2000). "On the Exact Science of Nonbeings", Iyyun, The Jerusalem Philosophical Quarterly 49, pp. 3-22.

Melamed, Y. (2009). "Spinoza's Metaphysics of Substance: The Substance-Mode Relation as a Relation of Inherence and Predication”, Philosophy and Phenomenological Research 78 , pp. $17-82$

Melamed, Y. (2010). "Acosmism or Weak Individuals? Hegel, Spinoza, and the Reality of the Finite", Journal of the History of Philosophy 48, pp. 77-92.

Miller, J. (2003). "Stoics, Grotius, and Spinoza on Moral Deliberation", in J. Miller and B. Inwood (eds) Hellenistic and Early Modern Philosophy. Cambridge: Cambridge University Press, pp. 116-40. 
Newlands, S. (2010). "Spinoza's Modal Metaphysics", in E.N. Zalta (ed.) Stanford Encyclopedia of Philosophy (Spring 2010 edn.), http://plato.stanford.edu/archives/spr2010/entries/ spinoza-modal.

Newlands, S. (2011). "Hegel's Idealist Reading of Spinoza”, Philosophy Compass 6(2), pp. $100-8$.

Ockham, W. of (1990). Philosophical Writings. Indianapolis, IN: Hackett.

Oliver, A. (1996). "The Metaphysics of Properties", Mind 105, pp. 1-80.

Pollock, F. (1880). Spinoza. London: C.K. Paul.

Rice, L. (1994). "Le nominalisme de Spinoza", Canadian Journal of Philosophy 24, pp. 19-32.

Savan, D. (1958). "Spinoza and Language", The Philosophical Review 67(2), pp.212-25.

Schliesser, E. (2014). "Spinoza and the Philosophy of Science: Mathematics, Motion, and Being", in Della Rocca 2014 op. cit.

Schmaltz, T. (1997). "Spinoza's Mediate Infinite Mode", Journal of the History of Philosophy 35, pp. 199-235.

Simons, P. (1994). "Particulars in Particular Clothing", Philosophy and Phenomenological Research 54, pp. 553-75.

Spinoza, B. (1925). Opera, ed. C. Gebhardt. Heidelberg: C. Winter.

Spinoza, B. (1984). The Collected Works of Spinoza, E. Curley, trans. Princeton, NJ: Princeton University Press.

Spinoza, B. (1995). The Letters, ed. S. Barbone, J. Adler and L. Rice; S. Shirley, trans. Indianapolis, IN: Hackett.

Steinberg, D. (1987). "Necessity and Essence in Spinoza", Modern Schoolman 64, pp. 187-95.

Suárez, F. (1995). On Beings of Reason. Milwaukee, WI: Marquette University Press.

Viljanen, V. (2011). Spinoza's Geometry of Power. Cambridge: Cambridge University Press.

Wilson, M. (1996). "Spinoza's Theory of Knowledge", in D. Garrett (ed.) The Cambridge Companion to Spinoza. Cambridge: Cambridge University Press, 89-141.

Wilson, M. (1999). "For They Do not Agree in Nature with Us": Spinoza and the Lower Animals', in Gennaro and Huenemann op. cit., pp. 336-51.

Yovel, Y. (1992). Spinoza and Other Heretics. Princeton, NJ: Princeton University Press. 